\title{
LA FEMME 100 TÊTES
}

Para compor seus romances-colagem, Max Ernst lança mão de ilustrações oitocentistas extraídas de periódicos, catálogos comerciais e técnicos, livros de divulgação científica, romances populares, relatos de viagens e memórias, dentre outros. O resultado é a criação de uma narrativa ambígua e elíptica, cuja metodologia de elaboração conjuga um vasto repertório iconográfico de uma maneira bastante peculiar. Traçando um paralelo, na presente edição do Anuário de Literatura publicamos textos em que palavras e imagens transitam livremente entre romances, poemas, filmes, textos filosóficos, hipertextos e livros de linhagem, para compor um mosaico rico de significados. Assim, como outrora Max Ernst buscou uma visão crítica da sociedade do século XIX, enraizada em categorias surrealistas e psicanalíticas, oferecemos a diversidade de abordagens e pensamentos, características marcantes de nosso tempo.

Não é coincidência, pois, que esta edição seja ilustrada com a imagem "Aqui estão todas juntas as minhas sete irmãs, vivendo frequentemente em desejos líquidos e parecendo perfeitas folhas adormecidas", uma imagem poética mas não menos enigmática, em que podemos ler uma alusão às sete artes, estudadas em alguma instância pelos textos, em que mais do que uma hierarquia encontramos um diálogo que as retira da inércia, perpassando os campos da música, da dança, da pintura, da escultura, do teatro e do cinema, tomando como eixo a literatura. Presente na obra La femme 100 têtes (1929), o título da narrativa também permite diversas possibilidades de interpretação, como "100 têtes" (100 cabeças), "sans tête" (sem cabeça), "s" entête" (obstina-se) e "sang tête" (sangue cabeça). Apropriandonos agora da imagem verbal, não buscamos estabelecer escalas de valor ou hierarquia entre os campos do pensamento, da fruição artística ou dos textos que deles se 
apropriam, mas uma edição em que muitas cabeças dialogam sem que haja uma única no centro, em que, obstinada e sanguínea, a literatura encontra no intelecto e na paixão o tom ideal da escrita e da leitura.

Para tanto, a edição atual é aberta por uma leitura do romance Hotel Atlântico, de João Gilberto Noll, em que Oziris Borges Filho opta pela perspectiva da topoanálise. Em seguida, no artigo "O louva-a-deus surrealista e os fantasmas da imagem", André Luiz do Amaral discute a representação do louva-a-deus pelos surrealistas, cujo procedimento alcança o clímax na análise paranóico-crítica de Salvador Dali sobre o Angelus de Milliet. Risolete Maria Hellmann oferece uma leitura de Palomar, de Italo Calvino, intitulada "O olhar pós-moderno: uma leitura de Palomar"; enquanto João Guilherme Dayrell estabelece relações entre a montagem cinematográfica e a fragmentada narrativa de Ruffato em "A montagem em Eles eram muitos cavalos, de Luiz Ruffato: conversações entre cinema e literatura". A relação cinema versus literatura também é abordada em "O foco nas narrativas literárias e fílmicas: olhares em um conto de Carlos Liscano e em Amores perros", em que Selomar Claudio Borges discorre acerca da incidência do foco narrativo na literatura e no cinema.

Em "Representações da tecnologia em alguns poemas da literatura brasileira", Rubel Maria Fanini analisa a representação literária do universo da tecnologia e do trabalho em alguns poemas de Castro Alves, Mário de Andrade e Oswald de Andrade. Estabelecendo um diálogo com o texto anterior, em "O hipertexto e o estranho: causas e efeitos", Everton Vinicius de Santa parte do conceito freudiano de "estranho", proposto por Freud em Das Unheimlich, para demonstrar como o hipertexto vem sendo responsável por uma espécie singular de "estranhamento" na relação obra/leitor. Finalmente, encerrando a seção de artigos, em "O Imaginário Cavaleiresco nos livros de linhagens da Idade Média Portuguesa uma abordagem semiótica", José D'Assunção Barroso examina algumas narrativas medievais da Idade Média portuguesa que aparecem nos livros de linhagens do século XIII, com vistas à identificação dos principais traços de um Imaginário Cavaleiresco que foi essencial para a formação da identidade nobiliárquica.

Abrindo a seção "Ensaios", temos o texto "Os folhetins perversos de Max Ernst" no qual Annateresa Fabris passa em revista dos três romances-colagem do escritor, entre os quais o referido La femme 100 têtes. Em "Delírios I - Agonia e experiência (Jogos de vida e morte)", Vinícius Nicastro Honesko, a partir da conceituação do termo "jogo" em Johan Huizinga e Roger Caillois, expõe a idéia de agonia como jogo de vida e morte no qual imerge o artista no ato de criação. Na sequência, no ensaio "Historias da infâmia: de Borges a Foucault", Kelvin Falcão Klein investiga o percurso do significante "infâmia" a partir de textos de Michel 
Foucault, Giorgio Agamben e Jorge Luis Borges. Em "Mula de Deus: o impossível pedido", por sua vez, Rubens da Cunha realiza uma análise do poema homônimo de Hilda Hilst, que compõe a narrativa Estar Sendo. Ter Sido, tomando como suporte teórico o texto "O fim do poema", de Giorgio Agamben. Encerrando esta seção, o ensaio "Veículos alegóricos em crônicas machadianas e em Novecento, de Alessandro Baricco", de Roberta Mataragi, utiliza a concepção de alegoria de Walter Benjamin como pressuposto teórico para uma leitura alegórica de dois meios de transporte: o bonde, presente em algumas crônicas de Machado de Assis, e o navio Virginian, transatlântico da ficção italiana Novecento, un monologo, de Alessandro Baricco.

Em "Resenha" apresentamos uma introdução, ou antes, o percurso mental de dois italianistas dedicados aos estudos do Futurismo, Andréia Guerini e Rafael Copetti, sobre o livro Futurismo: L'avanguardia delle avanguardie [Futurismo: a vanguarda das vanguardas], de autoria de Claudia Salaris.

Fechando a presente edição, em "Dossiê" disponibilizamos os melhores ensaios desenvolvidos no âmbito de um Curso ministrado no Programa de Pós-Graduação em Literatura, da Universidade Federal de Santa Catarina, ao longo do segundo semestre de 2009. Para orientar ou mesmo introduzir o leitor iniciante na complexidade do pensamento de JeanLuc Nancy que, embora figure entre os mais importantes filósofos franceses da atualidade ainda é pouco traduzido no Brasil, Carlos Eduardo Schmidt Capela, responsável pelo Curso, oferece-nos seu "Buquê sem perfumes nem rosas que são 13", seguido dos textos: "Pensando arte, poesia e literatura pela ótica de Jean-Luc Nancy", de José Oleriano Monteiro Filho; "Cinema com Nancy", de Artur de Vargas Giorgi; "Musa à Nação", de Jonas Tenfen; "O corpo aberto da musa", de George Luiz França; "Corpos que se abrem para dar à luz", de Vanessa Daniele de Moraes; "O mundo dos sentidos, os sentidos do mundo: de Bahamut a Jean-Luc Nancy", de Fernando Floriani Petry; "Thomas Bernhard: pensamento fenecido e sujeito ressucitado", Helano Jader Ribeiro.

Boa leitura!

\author{
Carolina Cerqueira de Lima Dittrich \\ Fernanda Müller \\ Rafael Zamperetti Copetti \\ Stélio Furlan
}

Comissão Editorial 